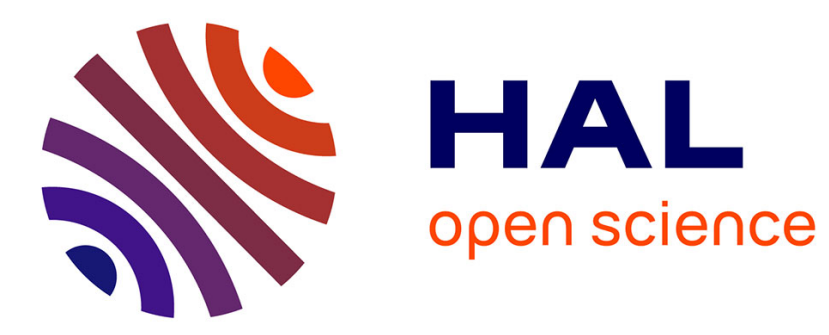

\title{
An In Vitro Approach To Study RNase III Activities of Plant RTL Proteins
}

Cyril Charbonnel, Anne de Bures, Julio Sáez-Vásquez

\section{To cite this version:}

Cyril Charbonnel, Anne de Bures, Julio Sáez-Vásquez. An In Vitro Approach To Study RNase III Activities of Plant RTL Proteins. RNA Remodeling Proteins, pp.363 - 385, 2020, 10.1007/978-10716-0935-4_23. hal-03121899

\section{HAL Id: hal-03121899 \\ https://hal-univ-perp.archives-ouvertes.fr/hal-03121899}

Submitted on 9 Feb 2021

HAL is a multi-disciplinary open access archive for the deposit and dissemination of scientific research documents, whether they are published or not. The documents may come from teaching and research institutions in France or abroad, or from public or private research centers.
L'archive ouverte pluridisciplinaire HAL, est destinée au dépôt et à la diffusion de documents scientifiques de niveau recherche, publiés ou non, émanant des établissements d'enseignement et de recherche français ou étrangers, des laboratoires publics ou privés. 


\section{Chapter 23}

\section{An in vitro approach to study RNase III activities of plant RTL proteins}

Cyril Charbonnel, Anne de Bures, and Julio Sáez-Vásquez ${ }^{\S}$

CNRS, Laboratoire Génome et Développement des Plantes, UMR 5096, 66860, Perpignan, France. Université Perpignan Via Domitia, Laboratoire Génome et Développement des Plantes, UMR 5096, 52 Avenue Paul Alduy, F-66860, Perpignan, France.

§To whom correspondence should be addressed

Fax: +33(0) 468668499

Email: saez@univ-perp.fr

Tel: +33(0) 430198118

Running Head: Plant RNase III 


\section{ABSTRACT}

RTL (RNase Three Like) proteins belong to a distinct family of endonucleases that cleave double stranded RNAs in plants. RTL1 to 3 are structurally related to the RNAse III from E. coli and formally belong to the class 1 of RNase III proteins. RTLs have conserved RNase III signature motif(s) and up to two dsRNA binding (DRB) domains. RTLs target and cleave coding and non-coding dsRNAs, including precursors of ribosomal (rRNA), small interference (siRNA) and micro (miRNA) RNAs. Interestingly, RTL proteins have stronger affinity than RNase III -Dicer proteins for dsRNA precursors of siRNAs, but not for miRNAs. However, very little is known of the structural and molecular bases directing and controlling RTL-RNA binding and activity. To address these questions, we have developed in vitro cleavage assays that combine recombinant RTL1 protein and in vitro transcribed or plant extracted RNAs, RT-PCR and primer extension experiments or analysis.

Keywords: RNase III, dsRBD, RNA cleavage, Arabidopsis thaliana, plants 


\section{Introduction}

Ribonucleases III (RNases III) are endonucleases that target and cleave double stranded RNA (dsRNA) [1]. The cleavage performed by RNases III generates 5'-phosphoryl and 3'-hydroxyl ends with a two-nucleotide (nt) 3'-overhang in their dsRNA products (Figure 1A). Found in bacteria and eukaryotes, RNases III are universally involved in processing and maturation of almost every class of RNA precursors into functional RNAs. All members of the RNase III family contain a characteristic RNase III domain, which has a highly conserved stretch of nine amino acid residues known as the RNase III signature motif. RNase III proteins vary widely in length, from 140 to 2000 amino acids and have been subdivided into four classes based on domain composition [1-4].

Class I is the simplest and the smallest, including Bacillus subtilis Mini-III with a single RNase III domain and bacterial Escherichia coli and Aquifex aeolicus RNases III that, in addition to the single RNase III domain, also contain a DRB domain [5-7]. Class II is identified by the presence of a highly variable N-terminal domain extension and includes the Saccharomyces cerevisiae Rnt1 and Saccharomyces pombe Pac1 proteins [8-10]. Class III proteins, including Drosha, have a DRB and two RNase III domains [11-13]. Class IV proteins correspond to Dicer and contain a RNA helicase domain, a PAZ domain, one or two RNase III signature domains and one or two DRB domains. Dicer proteins are the only RNase III proteins that have been shown to produce small RNAs, including siRNAs and miRNAs [14-17].

In the model plant Arabidopsis thaliana, two families of RNases III are present. The first family corresponds to DICER-LIKE (DCL) enzymes $[18,16]$. DCL1 is involved in the production of 21-nucleotide (nt) miRNAs $[19,20]$ while DCL2, DCL3 and DCL4 produce 22-, 24- and 21-nt siRNAs, respectively [21-24]. The 21-22-nt small RNAs produced by DCL1, DCL2 and DCL4 are loaded onto ARGONAUTE (AGO) proteins that cleave complementary RNAs to perform post- 
transcriptional gene silencing (PTGS), while 24-nt small RNAs produced by DCL3 are loaded onto AGO proteins to perform RNA-directed DNA methylation (RdDM) and transcriptional gene silencing (TGS) [25-27]. [Figure 1 near here]

The second RNase III family of $A$. thaliana corresponds to RNase Three-Like (RTL) enzymes and has three members (Figure 1B) [28]. AtRTL1 is a $\sim 34 \mathrm{kDa}$ protein containing single RNase III and DRB domains. AtRTL1 cleaves perfectly paired dsRNAs, before they are processed by DCL2, DCL3 or DCL4 in siRNA, thus suppressing siRNA production from more than 6,000 loci [29]. AtRTL2 is a $\sim 44 \mathrm{kDa}$ protein and contains a single RNase III and two DRB domains $[28,30]$. In contrast to the broad action of AtRTL1, AtRTL2 specifically modulates the expression of rDNA [28] and of $~ 500$ loci producing 24-nt siRNAs involved in RdDM [31]. RTL3 appears to be a pseudogene whose expression cannot be detected.

In addition to DCL and RTL protein families, two A. thaliana chloroplast Mini-RNase III-like (RNC3 and RNC4) have been described; it is believed that RNC3 and RNC4 might cleave rRNA and participate in intron recycling in the chloroplast [32].

Modelling of AtRTL1 [33] (Figure 2A) and AtRTL2 [28] proteins revealed antiparallel homo-dimerization of RNase III domains, similar to E. coli and A. aeolicus RNases III [5, 6]. AtRTL1 recognizes specific rcr1sequence (for RTL1 consensus region 1) and cleaves hairpin structure located in the 3'UTR of the A. thaliana At3g18145 gene (Figure 2B). Remarkably, AtRTLs and Dicer proteins contain a conserved cysteine in the DRB domain (Cys230 in AtRTL1; Figure 2A) [33]. In AtRTL1 cysteine glutathionlylation inhibits RNase III cleavage activity in a reversible manner. Therefore, biotic and abiotic stresses, which affect the cellular redox environment, could modulate the activity of AtRTL1, and likely AtRTL2 and DCLs, and contribute to a fine-tuned modulation of small RNAs and subsequent gene regulation [33]. 
To dissect the molecular (RNA/protein) bases regulating and controlling RNase III activity of RTLs, we have established an in vitro RNA cleavage assay using recombinant proteins expressed in E. coli, total RNA extracted from plant seedlings and in vitro transcribed RNAs (Figure 3). We use the RTL1 targets 3'UTR of the A. thaliana At3g18145 gene [5]. Beyond our studies of AtRTL1 protein and 3'UTR of At3g18145 target, we believe that this protocol could be useful and easily adapted to study other RNases III and/or dsRNA targets from other organisms. [Figure 2 near here]

\section{Materials}

\subsection{Production of Recombinant His-AtRTL1 Protein}

1. $150 \mathrm{ng} / \mu \mathrm{L}$ pET16b::AtRTL1 plasmid in sterile, deionized water, prepared as described previously [33, 29] (see Note 1).

2. SoluBL21 $1^{\mathrm{TM}}$ Competent E. coli cells (Genlantis) (see Note 2).

3. $1 \mathrm{M}$ Isopropyl $\beta$-D-thiogalactopiraniside (IPTG). Dissolve $2.38 \mathrm{~g}$ of IPTG in $10 \mathrm{~mL}$ of deionized $\mathrm{H}_{2} \mathrm{O}$. Sterilize the solution by passing it through a $0.2-\mu \mathrm{m}$ pore-size filter. Store in small aliquots at $-20^{\circ} \mathrm{C}$.

4. $100 \mathrm{mg} / \mathrm{mL}$ Ampicillin solution. Dissolve $1 \mathrm{~g}$ of ampicillin in $10 \mathrm{~mL}$ of deionized $\mathrm{H}_{2} \mathrm{O}$. Sterilize the solution by passing it through a $0.2-\mu \mathrm{m}$ pore-size filter. Store in small aliquots at $-20^{\circ} \mathrm{C}$.

5. LB (Luria-Bertani) medium: Dissolve $10 \mathrm{~g}$ of tryptone, $5 \mathrm{~g}$ of yeast extract and $1 \mathrm{~g}$ of $\mathrm{NaCl}$ in $950 \mathrm{~mL}$ of deionized $\mathrm{H}_{2} \mathrm{O}$. Adjust the $\mathrm{pH}$ to 7 with $5 \mathrm{~N} \mathrm{NaOH}$ and the final volume of the 
solution to $1 \mathrm{~L}$ with deionized $\mathrm{H}_{2} \mathrm{O}$. Sterilize by autoclaving and store the medium at room temperature.

6. M9 medium: mix $6 \mathrm{~g}$ of $\mathrm{Na}_{2} \mathrm{HPO}_{4}, 3 \mathrm{~g}$ of $\mathrm{KH}_{2} \mathrm{PO}_{4}, 0.5 \mathrm{~g}$ of $\mathrm{NaCL}$ in $800 \mathrm{~mL}$ of deionized $\mathrm{H}_{2} \mathrm{O}$. Sterilize by autoclaving and store the medium at room temperature. Before use, add the following sterile components: $1 \mathrm{~mL}$ of $100 \mathrm{mM} \mathrm{CaCl}_{2}, 1 \mathrm{~mL}$ of $1 \mathrm{M} \mathrm{MgSO}_{4}$ and $3 \mathrm{~mL}$ of $100 \%$ glycerol. Complete to $1 \mathrm{~L}$ with sterile deionized $\mathrm{H}_{2} \mathrm{O}$.

7. LB-ampicillin medium. Add $1 \mathrm{~mL}$ of $100 \mathrm{mg} / \mathrm{mL}$ ampicillin to $1 \mathrm{~L}$ of sterile $\mathrm{LB}$ medium

8. M9-ampicillin medium. Add $1 \mathrm{~mL}$ of $100 \mathrm{mg} / \mathrm{mL}$ ampicillin to $1 \mathrm{~L}$ of sterile $\mathrm{M} 9$ medium.

9. LB-ampicillin plates: Dissolve $1.5 \mathrm{~g}$ of agar in $100 \mathrm{~mL}$ of $\mathrm{LB}$ medium. After autoclaving, cool down the medium $\left(37-42{ }^{\circ} \mathrm{C}\right)$ and add $0.1 \mathrm{~mL}$ of $100 \mathrm{mg} / \mathrm{mL}$ ampicillin. Mix and pour the solution into petri dishes (use about $20 \mathrm{~mL}$ per dish). After solidification at room temperature, store the plates at $4^{\circ} \mathrm{C}$.

10. Petri dishes $85 \times 10 \mathrm{~mm}$

11. Water baths set to $42^{\circ} \mathrm{C}$.

12. Incubator chamber set to $37^{\circ} \mathrm{C}$.

13. Shaking incubator.

14. $0.2 \mu \mathrm{m}$ pore-size filters and $10 \mathrm{~mL}$ disposable syringes.

15. UV-vis spectrophotometer.

16. Centrifuge equipped with rotors holding $500 \mathrm{~mL}$ centrifuge bottles and $50 \mathrm{~mL}$ tubes. 


\subsection{Purification of Recombinant His-AtRTL1 Protein}

1. $1 \mathrm{~mL}$ Gravity flow column filled with Ni-NTA His-binding resin (see Note 3).

2. Gravity flow column holder or equivalent.

3. $1 \mathrm{X}$ His-binding buffer: $50 \mathrm{mM} \mathrm{NaH}{ }_{2} \mathrm{PO} 4, \mathrm{pH} 8.0 ; 300 \mathrm{mM} \mathrm{NaCl} ; 10 \mathrm{mM}$ imidazole.

4. 1X His-washing buffer: $50 \mathrm{mM} \mathrm{NaH} 2 \mathrm{PO} 4, \mathrm{pH} 8.0 ; 300 \mathrm{mM} \mathrm{NaCl} ; 20 \mathrm{mM}$ imidazole.

5. 1X His-elution buffer: $50 \mathrm{mM} \mathrm{NaH} 2 \mathrm{PO} 4, \mathrm{pH} 8.0 ; 300 \mathrm{mM} \mathrm{NaCl} ; 250 \mathrm{mM}$ imidazole.

6. Protein sample buffer: $20 \mathrm{mM}$ Tris- $\mathrm{HCl}, \mathrm{pH} 7.5,100 \mathrm{mM} \mathrm{NaCl}, 20 \%$ (v/v) glycerol, $1 \mathrm{mM}$ Ethylenediaminetetraacetic acid (EDTA), $1 \mathrm{mM}$ Dithiothreitol (DTT).

7. Protease inhibitor cocktail (e.g cOmplete, EDTA-freeProtease Inhibitor Cocktail from Roche).

8. $1 \mathrm{mg} / \mathrm{mL}$ DNase I. Stored at $-20^{\circ} \mathrm{C}$.

9. Protein extraction buffer: $1 \mathrm{X}$ binding buffer supplemented with $2.5 \mu \mathrm{M} \mathrm{MgCl}_{2}$ and $1 \mu \mathrm{g} / \mathrm{mL}$ DNase I. Prepare $20 \mathrm{~mL}$ of buffer per purification and dissolve 1 tablet of cOmplete, EDTAfreeProtease Inhibitor Cocktail (Roche) right before use.

10. $10 \%(\mathrm{w} / \mathrm{v})$ Ammonium persulfate (APS): Dissolve $1 \mathrm{~g}$ of APS in $10 \mathrm{~mL}$ of sterile deionized $\mathrm{H}_{2} \mathrm{O}$. Store in small aliquots at $-20^{\circ} \mathrm{C}$.

11. N,N,N,N-Tetramethylethylenediamine (TEMED). Stored at $4^{\circ} \mathrm{C}$

12. $40 \%$ Acylamide/bis-acrylamide (29:1 ratio). Stored at $4{ }^{\circ} \mathrm{C}$.

13. $20 \%$ (w/v) Sodium dodecyl sulfate (SDS) in sterile deionized $\mathrm{H}_{2} \mathrm{O}$.

14. System for polyacrylamide gel electrophoresis (PAGE) and power supply. 
15. Homemade $10 \%$ SDS-PAGE gel or commercial precast gel equivalent. For a homemade gel using $10 \times 8 \mathrm{~cm}$ gel plates with $0.75 \mathrm{~mm}$ spacers, prepare $8 \mathrm{~mL}$ of $10 \%$ resolving mix: $3.8 \mathrm{~mL}$ of deionized $\mathrm{H}_{2} \mathrm{O}, 2 \mathrm{~mL}$ of $40 \%$ Acylamide/bis-acrylamide (29:1), $2 \mathrm{~mL}$ of 1.5M Tris-HCl pH $8.8,40 \mu \mathrm{l}$ of $20 \%(\mathrm{w} / \mathrm{v}) \mathrm{SDS}, 80 \mu \mathrm{l}$ of $10 \%(\mathrm{w} / \mathrm{v})$ APS, $8 \mu \mathrm{l}$ of TEMED. Also prepare, $5 \mathrm{~mL}$ of $6 \%$ stacking solution mix: $2.9 \mathrm{~mL}$ of deionized $\mathrm{H}_{2} \mathrm{O}, 0.75 \mathrm{~mL}$ of $40 \%$ Acylamide/bisacrylamide (29:1), $1.25 \mathrm{~mL}$ of $0.5 \mathrm{M}$ Tris- $\mathrm{HCl} \mathrm{pH} 6.8,50 \mu \mathrm{L}$ of $20 \%$ (w/v) SDS, $50 \mu \mathrm{L}$ of $10 \%$ (w/v) APS, $5 \mu \mathrm{L}$ of TEMED. APS and TEMED should be added to each mix only right before pouring the gel.

16. $1 X$ SDS-PAGE running buffer: $0.025 \mathrm{M}$ Tris, $0.192 \mathrm{M}$ glycine, $0.1 \%$ (w/v) SDS. The $\mathrm{pH}$ of the buffer should be 8.3 .

17. $2 \mathrm{X}$ sample loading buffer (Laemmli buffer): $0.125 \mathrm{M}$ Tris-HCl, $\mathrm{pH} 6.7 ; 4 \%$ (w/v) SDS; $20 \%$ (v/v) glycerol, $0.05 \%(w / v)$ Bromophenol blue.

18. 14.3 M $\beta$-mercaptoethanol. Stored at $4^{\circ} \mathrm{C}$.

19. Commercial protein ladder covering the $10-250 \mathrm{kDa}$ range. Stored at $-20^{\circ} \mathrm{C}$.

20. Protein gel staining solution (e.g. Symply Blue solution from Invitrogen).

21. Destaining gel solution: $10 \%(\mathrm{v} / \mathrm{v})$ glacial acetic acid, $20 \%(\mathrm{v} / \mathrm{v})$ methanol.

22. Protein dosage kit containing Bradford reagent and bovine serum albumin (BSA) concentration standard.

23. Size exclusion column (SEC) buffer: $50 \mathrm{mM}$ Tris- $\mathrm{HCl} \mathrm{pH} 7.5,5 \mathrm{mM} \mathrm{MgCl} 2,150 \mathrm{mM} \mathrm{NaCl}$.

24. Protein standards conalbumin $(75 \mathrm{kDa})$, ovalbumin $(43 \mathrm{kDa})$ and carbonic anhydrase $(29 \mathrm{kDa})$ (e.g. Gel filtration calibration kit LMW from GE-Healthcare). 
25. $100 \%$ Glycerol.

26. Fast Protein Liquid Chromatography (FPLC) instrument.

27. Superdex 75 10/300 GL column (GE Healthcare).

28. UV-vis spectrophotometer.

29. 8,000 Molecular weight cut-off (MWCO) dialysis bags.

30. $0.45-\mu \mathrm{m}$ pore-size filters and $10 \mathrm{~mL}$ disposable syringes.

31. Benchtop centrifuge (refrigerated) and vortex mixer.

32. Dry bath set to $95^{\circ} \mathrm{C}$.

33. Cell disruptor system.

\subsection{Plant Total RNA Extraction and DNase treatment}

1. Deionized, RNase-free water. Guaranteed high-grade (RNase/DNase-free, DEPC-treated, etc.) $\mathrm{H}_{2} \mathrm{O}$ can be obtained from various commercial sources.

2. UV-vis spectrophotomer with microliter volume capability (e.g. NanoDrop 2000 from Thermo Scientific).

3. $\quad 0.1 \mathrm{~g}$ of 14-day-old A. thaliana seedlings, grown as described previously [33].

4. Glass beads (1.7-2.1 mm diameter).

5. Mixing device (e.g. Silamat S6 from Ivoclar Vivadent).

6. Trizol reagent, stored at $4^{\circ} \mathrm{C}$. 
7. Chloroform, stored at $4^{\circ} \mathrm{C}$.

8. Isopropanol, stored at room temperature.

9. Chloroform:Isoamyl alcohol (24:1). Mix $24 \mathrm{~mL}$ of chloroform with $1 \mathrm{~mL}$ of isoamyl alcohol. Stored at $4{ }^{\circ} \mathrm{C}$.

10. Ethanol absolute ( $\geq 99.8 \%)$. Stored at $-20^{\circ} \mathrm{C}$.

11. $75 \%(\mathrm{v} / \mathrm{v})$ ethanol in deionized, RNase-free water. Stored at $-20^{\circ} \mathrm{C}$.

12. Turbo DNA-free kit (ThermoFisher Scientific) containing Turbo DNase, $10 \mathrm{X}$ Turbo DNase buffer, and DNase inactivation reagent.

13. Agarose.

14. 50X TAE buffer: $2 \mathrm{M}$ Tris- $\mathrm{HCl} \mathrm{pH} 8,1 \mathrm{M}$ glacial acetic acid, $50 \mathrm{mM}$ EDTA.

15. 10X MOPS buffer: $0.2 \mathrm{M}$ MOPS $\mathrm{pH} 7,50 \mathrm{mM}$ sodium acetate, $10 \mathrm{mM}$ EDTA

16. Dye mix: Mix and dissolve $25 \mathrm{mg}$ of bromophenol blue, $25 \mathrm{mg}$ of xylene cyanol $\mathrm{FF}$ and 3.3 $\mathrm{mL}$ of $100 \%$ glycerol in $6.7 \mathrm{~mL}$ of sterile deionized $\mathrm{H}_{2} \mathrm{O}$. Stored at $-20^{\circ} \mathrm{C}$.

17. Agarose RNA loading buffer (prepare just before use): Mix $10 \mu \mathrm{L}$ of deionized formamide, 10 $\mu \mathrm{L}$ of formadehyde, $2 \mu \mathrm{l}$ of $10 \mathrm{X}$ MOPS buffer and $1 \mu \mathrm{l}$ of dye mix. Stored at $-20^{\circ} \mathrm{C}$.

18. GelRed® Nucleic Acid Gel Stain (Biorad) or equivalent.

19. Benchtop centrifuge (refrigerated) and vortex mixer.

20. Horizontal gel electrophoresis system for agarose gels with power supply.

21. Standard transilluminator (302 or $312 \mathrm{~nm}$ ). 
22. Dry baths set to $37^{\circ} \mathrm{C}$.

23. Liquid nitrogen.

24. Rotating mixer.

\subsection{His-AtRTL1 Cleavage Activity and RT-PCR assays}

1. Items $1,13,14$ and 18-21 from Section 2.3.

2. 5X Cleavage reaction buffer: $100 \mathrm{mM}$ Tris- $\mathrm{HCl} \mathrm{pH} 7.5,50 \mathrm{mM} \mathrm{MgCl} 2$

3. One-Step RT-PCR Kit (Qiagen) containing One Step Buffer 5X, 10 mM dNTPs, Q-Solution and One-Step RT enzyme. Stored at $-20^{\circ} \mathrm{C}$.

4. $160 \mathrm{U} / \mu \mathrm{L}$ GoScript ${ }^{\mathrm{TM}}$ Reverse Transcriptase (RT) and GoScript ${ }^{\mathrm{TM}} 5 \mathrm{X}$ reaction buffer (Promega) or equivalent. Stored at $-20^{\circ} \mathrm{C}$.

5. $40 \mathrm{U} / \mu \mathrm{L}$ RNasin (Promega) or equivalent. Stored at $-20^{\circ} \mathrm{C}$.

6. $10 \mathrm{mM}$ dGTP, dATP, dTTP, dCTP stock solution. Stored at $-20^{\circ} \mathrm{C}$.

7. $10 \mathrm{mM} \mathrm{MgCl} 2$

8. 6X Agarose gel loading dye: Mix and dissolve $25 \mathrm{mg}$ of bromophenol blue and $3 \mathrm{~mL}$ of $100 \%$ glycerol in $7 \mathrm{~mL}$ of sterile deionized $\mathrm{H}_{2} \mathrm{O}$.

9. $5 \mathrm{U} / \mu \mathrm{L}$ Go®Taq DNA Polymerase and $5 \mathrm{X}$ Go®Taq buffer (Promega or equivalent). Stored at $-20^{\circ} \mathrm{C}$.

10. Dry baths set to $37^{\circ} \mathrm{C}$ and $70^{\circ} \mathrm{C}$. 
11. Thermocycler.

12. $10 \mu \mathrm{M}$ UTRrt, UTRfw, UTRrev, U3fw and U3rev primer solutions. Stored at $-20^{\circ} \mathrm{C}$. (Table 1). [Table 1 near here]

\subsection{His-AtRTL1 Cleavage Activity Assay and Mapping Cleavage site}

1. Items 10 and 11 from section 2.2 .

2. Items 2,5 and 6 from section 2.4 .

3. Deionized, RNase-free water.

4. $50 \mu \mathrm{Ci} / \mu \mathrm{L}, 3000 \mathrm{mmol} / \mathrm{mL}\left[\gamma^{32} \mathrm{P}\right] \mathrm{ATP}$. Handle and store at $-20^{\circ} \mathrm{C}$, following proper radiosafety regulation.

5. Plexiglas shields and containers for handling ${ }^{32} \mathrm{P}$-containing reagents and waste.

6. T4 PolyNucleotide Kinase (PNK), with $10 \mathrm{X}$ PNK buffer. Stored at $-20^{\circ} \mathrm{C}$.

7. $0.2 \mu \mathrm{m}$ and $0.45 \mu \mathrm{m}$ pore-size filters with $10 \mathrm{~mL}$ and $50 \mathrm{~mL}$ disposable syringes.

8. MicroSpin G-25 columns.

9. Superscript II RT Kit (Invitrogen), containing Superscript II RT enzyme, 5X Superscript II RT buffer and $100 \mathrm{mM}$ DTT. Stored at $-20^{\circ} \mathrm{C}$.

10. $3 \mathrm{M}$ Sodium acetate $\mathrm{pH}$ 5.2. Dissolve $24.6 \mathrm{~g}$ of sodium acetate (anhydrous) in $70 \mathrm{~mL}$ of deionized $\mathrm{H}_{2} \mathrm{O}$. Adjust the $\mathrm{pH}$ to 5.2 by adding glacial acetic acid and complete to $100 \mathrm{~mL}$ with deionized $\mathrm{H}_{2} \mathrm{O}$. Sterilize the solution by passing it through $0.2 \mu \mathrm{m}$ filter membrane.

11. Ethanol absolute $(\geqslant 99.8 \%)$ stored at $-20^{\circ} \mathrm{C}$. 
12. Ethanol $80 \%(\mathrm{v} / \mathrm{v})$ in deionized, RNase-free water and stored at $-20^{\circ} \mathrm{C}$.

13. $5 \mathrm{mg} / \mathrm{mL}$ yeast tRNA. Dissolve $5 \mathrm{mg}$ of yeast tRNA in $1 \mathrm{~mL}$ of deionized, RNase-free $\mathrm{H}_{2} \mathrm{O}$. Stored at $-20^{\circ} \mathrm{C}$.

14. Formamide loading buffer: Mix and dissolve $9.5 \mathrm{~mL}$ of deionized formamide, $2.5 \mathrm{mg}$ of xylene cyanol FF, $2.5 \mathrm{mg}$ of bromophenol blue, $100 \mu \mathrm{L}$ of $0.5 \mathrm{M}$ EDTA pH 8 and $400 \mu \mathrm{L}$ of deionized sterile $\mathrm{H}_{2} \mathrm{O}$. Store at $-20^{\circ} \mathrm{C}$.

15. 10X TBE: $0.89 \mathrm{M}$ Tris-base, $0.89 \mathrm{M}$ boric acid, $20 \mathrm{mM}$ EDTA.

16. $30 \%$ Acylamide/bis-acrylamide (19:1 ratio).

17. Urea, high quality grade.

18. Vertical gel electrophoresis system with $42 \times 20 \mathrm{~cm}$ and $22 \times 20 \mathrm{~cm}$ glass plates, $0.4 \mathrm{~mm}$ spacers, 20 teeth-comb, and power supply.

19. Denaturing, $6 \%$ Urea-PAGE gel: Dissolve 21 gr of urea in $20 \mathrm{~mL}$ of deionized $\mathrm{H}_{2} \mathrm{O}, 10 \mathrm{~mL}$ of 30\% Acrylamide/bis-acrylamide (19:1) and $5 \mathrm{~mL}$ of 10X TBE buffer. Warm the solution while mixing periodically to ensure complete dissolution (for instance using a $30{ }^{\circ} \mathrm{C}$ water bath). After urea is completely dissolved, complete to $50 \mathrm{~mL}$ with deionized $\mathrm{H}_{2} \mathrm{O}$. Filter the solution by passing it through a $0.45 \mu \mathrm{m}$ filter membrane. Add $300 \mu \mathrm{L}$ of $10 \%(\mathrm{w} / \mathrm{v}$ ) APS and $22 \mu \mathrm{L}$ of TEMED and immediately pour the gel within gel plates assembled following manufacturer's instructions. Then, install comb and let gel polymerize for about $60 \mathrm{~min}$.

20. $100 \mathrm{ng} / \mu \mathrm{L}$ pBSIIk-3'UTR plasmid in sterile, deionized water, prepared as described previously [33] (see Note 4).

21. $10 \mu \mathrm{M}$ primers pe1 and pe2 (Table 1). 
22. Benchtop centrifuge (refrigerated) and vortex mixer.

23. Dry baths set to $37^{\circ} \mathrm{C}, 52^{\circ} \mathrm{C}, 80^{\circ} \mathrm{C}$ and $95^{\circ} \mathrm{C}$.

24. Whatman paper $3 \mathrm{~mm}$ (46 x $57 \mathrm{~cm}$ sheets).

25. Saran Wrap.

26. Vacuum heated gel dryer.

27. Personal Molecular Imager (BioRad or equivalent), with ${ }^{32} \mathrm{P}$ imaging screen and cassette.

\subsection{His-AtRTL1 Cleavage Activity Assay Using Radiolabelled RNA probes}

1. Items 7-19 and 22-27 from Section 2.5.

2. $5 X$ Cleavage reaction buffer: $100 \mathrm{mM}$ Tris- $\mathrm{HCl} \mathrm{pH} 7.5,50 \mathrm{mM} \mathrm{MgCl}$.

3. $100 \mathrm{ng} / \mu \mathrm{L} \mathrm{pBSIIk}+3$ 'UTRrcr plasmid in sterile, deionized water, prepared as described previously [33] (see Note 4).

4. $10 \mathrm{U} / \mu \mathrm{L} \mathrm{Kpn} 1$ restriction enzyme with supplied $10 \mathrm{X}$ buffer. Stored at $-20^{\circ} \mathrm{C}$.

5. DNA cleanup kit (e.g. GeneClean Turbo kit from MP biochemicals). Stored at $-4^{\circ} \mathrm{C}$.

6. $10 \mu \mathrm{Ci} / \mu \mathrm{L}, 3000 \mathrm{Ci} / \mathrm{mmol}\left[\alpha^{3}{ }^{32} \mathrm{P}\right] \mathrm{CTP}$. Handle and store at $-20^{\circ} \mathrm{C}$, following proper radiosafety regulation.

7. Plexiglas shields and containers for handling ${ }^{32} \mathrm{P}$-containing reagents and waste.

8. Scalpel blade.

9. Riboprobe ${ }^{\circledR} \mathrm{T} 3$ transcription System (Promega) containing $5 \mathrm{X}$ Transcription buffer, $100 \mathrm{mM}$ DTT, $10 \mathrm{mM}$ rNTP stock solutions, and $20 \mathrm{U} / \mu \mathrm{L}$ T3 RNA Polymerase. Stored at $-20^{\circ} \mathrm{C}$. 
10. RNA elution solution: $0.5 \mathrm{M}$ ammonium acetate, $1 \mathrm{mM}$ EDTA, $100 \mathrm{mM}$ Tris- $\mathrm{HCl} \mathrm{pH} 8,0.05 \%$ $(w / v)$ SDS.

11. Phenol:chloroform:isoamyl alcohol (25:24:1), pH 5.2 premix solution.

12. Dry baths set to $37^{\circ} \mathrm{C}, 70^{\circ} \mathrm{C}$ and $95^{\circ} \mathrm{C}$.

3 Methods [Figure 3 near here]

\subsection{Production of Recombinant His-AtRTL1 Protein (Figure 3A)}

1. On ice, mix $0.5 \mu \mathrm{L}$ of the $150 \mathrm{ng} / \mu \mathrm{L}$ pET16b::AtRTL1 plasmid stock (see Note 1) with $50 \mu \mathrm{L}$ of SoluBL21 Competent E. coli cells (see Note 2). Incubate for $20 \mathrm{~min}$ on ice and then for 45 $\mathrm{s}$ at $42^{\circ} \mathrm{C}$. Add $250 \mu \mathrm{L}$ of LB medium and incubate and shake $(150 \mathrm{rpm})$ for $1 \mathrm{~h}$ at $37^{\circ} \mathrm{C}$.

2. Streak two LB-ampicillin plates with, respectively, $20 \mu \mathrm{L}$ and $200 \mu \mathrm{L}$ of the cell mixture from step 1 to isolate single colonies (see Note 5). Incubate overnight at $37^{\circ} \mathrm{C}$.

3. Select a well-isolated colony from the plates and use it to inoculate $100 \mathrm{~mL}$ of LB-ampicillin medium. Shake (150 rpm) overnight at $37^{\circ} \mathrm{C}$.

4. Transfer $50 \mathrm{~mL}$ of the overnight culture to $950 \mathrm{~mL}$ of $\mathrm{M} 9$-ampicillin medium. Shake (150 rpm) at $37^{\circ} \mathrm{C}$ and monitor the optical density at $600 \mathrm{~nm}\left(\mathrm{OD}_{600}\right)$ with a spectrophotometer.

5. When the $\mathrm{OD}_{600}$ reaches $\sim 0.4$, remove a $1 \mathrm{~mL}$ culture aliquot (non-induced control) and store it at $-20^{\circ} \mathrm{C}$ until further use. Then, add $1 \mathrm{~mL}$ of $1 \mathrm{M}$ IPTG to the remaining culture and shake (150 rpm) overnight at room temperature. 
6. Remove a $1 \mathrm{~mL}$ aliquot (induced control) and store it at $-20^{\circ} \mathrm{C}$. Then, transfer the overnight culture in two $500 \mathrm{~mL}$ centrifuge bottles. Harvest cells by centrifugation at $12,000 \mathrm{x} g$ for 15 $\min$ at $4^{\circ} \mathrm{C}$.

7. Suspend and pool cell pellets in $45 \mathrm{~mL}$ of M9-ampicillin medium and transfer the suspension into a $50 \mathrm{~mL}$ centrifuge tube. Harvest the cells by centrifugation at $12,000 \times \mathrm{g}$ for $15 \mathrm{~min}$ at $4^{\circ} \mathrm{C}$.

8. Remove the supernatant and store the pellet at $-80^{\circ} \mathrm{C}$.

\subsection{Purification of Recombinant His-AtRTL1 Protein (Figure 3A)}

\subsubsection{His-Affinity column purification}

1. Prepare and equilibrate a $1 \mathrm{~mL}$ His-binding resin column according to the manufacturer's instructions. Use a gravity-flow column holder or equivalent.

2. Suspend the cell pellet from section 3.1, step 8 in $10 \mathrm{~mL}$ of Protein extraction buffer.

3. Lyse the cells and release the proteins (see Note 6).

4. Collect the lysate and centrifuge at $7,800 \times \mathrm{g}$ for $20 \mathrm{~min}$ at $4^{\circ} \mathrm{C}$.

5. Load the $\sim 20 \mathrm{~mL}$ supernatant onto the $1 \mathrm{~mL}$ His-binding resin column from step 1 .

6. Wash the column with 10 volumes of $1 \mathrm{X}$ His-binding buffer and then with 6 volumes of $1 \mathrm{X}$ His-washing buffer.

7. Elute His-AtRTL1 with five volumes of $1 \mathrm{X}$ His-elution buffer. Collect up to 5 fractions (E1-5) of $1 \mathrm{~mL}$. 
8. Determine the protein concentration of each fraction using a Bradford protein dosage kit and following the kit's instructions.

9. Prepare samples containing $10 \mu \mathrm{L}$ of each E1-5 fraction, $10 \mu \mathrm{L}$ of $2 \mathrm{X}$ sample loading buffer, and $1 \mu \mathrm{L}$ of $\beta$-mercaptoethanol. Heat samples in a dry bath for 2 min at $95{ }^{\circ} \mathrm{C}$. Then spin the tube briefly in a microcentrifuge so that all the sample can be collected at the bottom.

10. Install homemade or precast $10 \%$ SDS-PAGE gel into vertical electrophoresis system. Fill the system tank(s) with $1 \mathrm{X}$ SDS-PAGE running buffer.

11. Load samples from step 7 and a protein ladder aliquot into separate gel wells. Also load beforeand after-induction samples from section 3.1, steps 5 and 6 .

12. Perform electrophoresis at $130 \mathrm{~V}$ until the dye front (the bromophenol blue) reaches the bottom of the gel.

13. Remove gel plates and place the gel into a tray filled with protein gel staining solution. Gently rock at room temperature for 30-60 min. Then throwaway protein gel staining solution and refill the tray with distaining gel solution. Gently rock at room temperature until the protein bands become visible on the gel. The His-AtRTL1 protein should be visible as a band migrating around $35 \mathrm{kDa}$ (see Note 7).

14. Use the Bradford concentration and SDS-PAGE analyses (see steps 8 and 13) to identify the fractions containing the largest and purest amounts of His-AtRTL1 protein (usually E2-E4). Combine these fractions for a second round of purification (step 15, optional) or proceed directly to step 18 . 
15. Load the pooled fractions into a dialysis bag and perform dialysis in $1 \mathrm{~L}$ of $1 \mathrm{X}$ His-binding buffer overnight at $4^{\circ} \mathrm{C}$ (see Note 8 ).

16. Recover the sample from the dialysis bag and centrifuge it at $18,000 \times \mathrm{g}$ for $20 \mathrm{~min}$ at $4^{\circ} \mathrm{C}$.

17. Recover the $\sim 5 \mathrm{~mL}$ supernatant and repeat steps 5 to 14 , using a new His-binding resin column (step 1).

18. Load the pooled fractions into a dialysis bag and perform dialysis in $1 \mathrm{~L}$ of Protein sample buffer overnight at $4^{\circ} \mathrm{C}$ (see Note 8).

19. Recover the sample from the dialysis bag and centrifuge it at $18,000 \mathrm{x} g$ for $20 \mathrm{~min}$ at $4{ }^{\circ} \mathrm{C}$.

20. Recover the supernatant and store it in $500 \mu \mathrm{L}(\sim 400 \mu \mathrm{g})$ aliquots at $-80^{\circ} \mathrm{C}$.

\subsubsection{Size Exclusion Chromatography (SEC)}

To purify His-AtRTL1 further and/or to remove any potential His-AtRTL1 degradation products, we recommend performing SEC using a Superdex 75 column connected to a FPLC system.

1. Connect the Superdex 75 column to a FPLC system and equilibrate it overnight with SEC running buffer. Set the FPLC system to perform SEC runs for at least 1.5 column volumes $(\sim 35$ $\mathrm{mL}$ ) at a flow rate of $0.5 \mathrm{~mL} / \mathrm{min}$.

2. Determine the elution volumes for molecular weight markers conalbumin ( $75 \mathrm{kDa})$, ovalbumin (43 kDa), and carbonic anhydrase $(29 \mathrm{kDa})$ by performing separate SEC runs with each protein. Use samples containing $1 \mathrm{mg}$ of protein in $500 \mu \mathrm{L}$ of SEC running buffer (see Note 9). 
3. On ice, thaw a $500 \mu \mathrm{L}$ aliquot of His-AtRTL1 from section 3.2.1, step 20 and load it on the Superdex 75 column. Perform a SEC run, collecting $0.5 \mathrm{~mL}$ fractions during the whole run.

4. Analyze peak fractions eluting between molecular weight markers conalbumin and carbonic anhydrase by SDS-PAGE as described in Section 3.2.1, steps 8-13 (see Note 10).

5. Combine fractions containing the most and purest His-AtRTL1 protein. Add to $500 \mu \mathrm{L}$ sample $125 \mu \mathrm{L}$ of $100 \%$ glycerol for a final concentration of $20 \%(\mathrm{v} / \mathrm{v})$.

6. Store at $-80^{\circ} \mathrm{C}$ as $100 \mu \mathrm{L}$ aliquots.

\subsection{His-AtRTL1 Cleavage Activity Assay Using Plant Total RNA}

\subsubsection{Total RNA extraction and DNase treatment}

1. Mix $\sim 0.1 \mathrm{~g}$ of the 14 -day-old $A$. thaliana seedlings in a $1.5 \mathrm{~mL}$ microtube with $\sim 10$ glass beads and freeze in liquid nitrogen.

2. Shake the samples for $8 \mathrm{~s}$ in a Silamat S6 mixing device and freeze in liquid nitrogen (see Note 11).

3. Repeat step 2 three times.

4. In a fume hood add to the grinded plant seedlings, $1 \mathrm{~mL}$ of Trizol reagent and mix thoroughly with a vortex mixer. Incubate $5 \mathrm{~min}$ at room temperature.

5. Add $0.2 \mathrm{~mL}$ of chloroform and incubate $2-3 \mathrm{~min}$ at room temperature.

6. Centrifuge at $12,000 \times g$ for $15 \mathrm{~min}$ at $4^{\circ} \mathrm{C}$. 
7. Recover the aqueous (upper) phase and transfer it into a new $1.5 \mathrm{~mL}$ microtube. Add $0.5 \mathrm{~mL}$ of isopropanol and incubate for $10 \mathrm{~min}$ at room temperature.

8. Centrifuge at $12,000 \mathrm{x} g$ for $10 \mathrm{~min}$ at $4^{\circ} \mathrm{C}$.

9. Discard the supernatant by inverting the tubes very gently and rinse the pellet by adding $1 \mathrm{~mL}$ of cold $75 \%$ ethanol.

10. Centrifuge at $7,500 \mathrm{x} g$ for $5 \mathrm{~min}$ at $4^{\circ} \mathrm{C}$. Remove carefully the supernatant and air dry the pellet at room temperature.

11. Suspend the RNA pellet in $40 \mu \mathrm{L}$ of deionized, RNase-free water. Estimate RNA concentration (see Note 12).

12. To remove genomic DNA contamination, set up a Turbo DNase reaction by mixing $10-15 \mu \mathrm{g}$ of total RNA, $5 \mu \mathrm{L}$ of $10 \mathrm{X}$ Turbo DNase buffer, $1 \mu \mathrm{L}$ of Turbo DNase, and deionized, RNasefree $\mathrm{H}_{2} \mathrm{O}$ up to a final volume of $50 \mu \mathrm{L}$. Incubate for $30 \mathrm{~min}$ at $37^{\circ} \mathrm{C}$.

13. Spin the tube briefly so that all the sample can be collected at the bottom and add an extra 0.5 $\mu \mathrm{L}$ of Turbo DNase to the mix and incubate for another $30 \mathrm{~min}$ at $37^{\circ} \mathrm{C}$.

14. Inactivate Turbo DNase by adding $5 \mu \mathrm{L}$ of inactivating solution from the Turbo DNA-free Kit (see Note 13). Incubate $5 \mathrm{~min}$ at room temperature in a rotating mixer.

15. Centrifuge at $10,000 \times \mathrm{g}$, for $1.5 \mathrm{~min}$ at $4^{\circ} \mathrm{C}$. Recover the supernatant and estimate RNA concentration (see Note 12).

16. Prepare a $0.8 \%(\mathrm{w} / \mathrm{v})$ agarose gel by mixing $0.8 \mathrm{~g}$ of agarose in $100 \mathrm{~mL}$ of $1 \mathrm{X}$ TAE buffer. Heat the mixture in a microwave oven until the solution is clear and the agarose is completely dissolved, add $10 \mu \mathrm{L}$ of gel GelRed® Nucleic Acid Gel Stain, and pour it in a gel tray (use a 
dedicated gel casting system or sealing tape to avoid gel leaking). Install comb and wait for the gel to solidify ( $\sim 15 \mathrm{~min})$. Then, install the gel in a horizontal electrophoresis system filled with 1X TAE buffer.

17. Mix $2.5 \mu \mathrm{L}$ of RNA sample $(\sim 10 \mu \mathrm{g})$ from step 18 with $10 \mu \mathrm{L}$ of Agarose RNA loading buffer and $7.5 \mu \mathrm{L}$ of deionized, RNase-free $\mathrm{H}_{2} \mathrm{O}$. Load sample in gel well and run gel for approximately $40 \mathrm{~min}$ at $75 \mathrm{~V}$.

18. Visualize RNA with a standard transilluminator (see Note 14).

19. Store RNA from step 15 at $-80^{\circ} \mathrm{C}$ until further use.

\subsubsection{Cleavage activity assay and One Step RT-PCR reaction (Figure 3B)}

1. Set up cleavage reactions by mixing $4 \mu \mathrm{L}$ of $5 X$ Cleavage reaction buffer, $0.5 \mu \mathrm{g}$ of total RNA (from Section 3.3.1, step 19), $0.2 \mu \mathrm{g}$ of His-AtRTL1 (from Section 3.2.1, step 20 or Section 3.2.2, step 6), and RNase-free $\mathrm{H}_{2} \mathrm{O}$ up to a final volume of $20 \mu \mathrm{L}$. Also prepare a cleavage reaction with Protein sample buffer instead of His-AtRTL1 protein (see Note 15). Incubate cleavage reaction mixes (with and without AtHis-RTL1) for 30 min at $37^{\circ} \mathrm{C}$.

2. Stop the cleavage reaction by heating samples $5 \mathrm{~min}$ at $70^{\circ} \mathrm{C}$. Then spin the tube briefly so that all the sample can be collected at the bottom.

3. Set up One Step RT-PCR reactions by mixing $5 \mu \mathrm{L}$ of $5 \mathrm{X}$ One Step buffer, $1 \mu \mathrm{L}$ of $10 \mathrm{mM}$ dNTPs, $5 \mu \mathrm{L}$ of Q-Solution, $1.5 \mu \mathrm{L}$ of $10 \mu \mathrm{M}$ UTRfw, $1.5 \mu \mathrm{L}$ of $10 \mu \mathrm{M}$ UTRrev, $1 \mu \mathrm{L}$ of One Step RT Enzyme, $2.5 \mu \mathrm{L}$ of cleavage mix reactions (from step 1, with or without His-RTL1), 
and RNase-free $\mathrm{H}_{2} \mathrm{O}$ up to a final volume of $25 \mu \mathrm{L}$. Also prepare One Step RT-PCR mix reactions with $1.5 \mu \mathrm{L}$ of $10 \mu \mathrm{M}$ U3fw and $1.5 \mu \mathrm{L}$ of $10 \mu \mathrm{M}$ U3rev (see Note 16).

4. Perform One Step RT-PCR program with the following parameters: step 1, RT reaction $\left(50^{\circ} \mathrm{C}, 30 \mathrm{~min}\right)$; step 2 , initial denaturation $\left(95^{\circ} \mathrm{C}, 15 \mathrm{~min}\right)$; step 3 , second cycle of denaturation $\left(95^{\circ} \mathrm{C}, 45 \mathrm{~s}\right)$; step 4, annealing $\left(52^{\circ} \mathrm{C}, 45 \mathrm{~s}\right)$; step 5, extension $\left(72^{\circ} \mathrm{C}, 90 \mathrm{~s}\right)$; step 6, final extension $\left(72^{\circ} \mathrm{C}, 10 \mathrm{~min}\right)$. Repeat steps $3-5,34$ times.

5. Prepare a $1.2 \%(\mathrm{w} / \mathrm{v})$ agarose gel as described in Section 3.3.1, step 16.

6. Mix $\sim 2-5 \mu \mathrm{L}$ of RT-PCR reactions from step 4 with $1.6 \mu \mathrm{L}$ of $6 \mathrm{X}$ Agarose gel loading dye and deionized $\mathrm{H}_{2} \mathrm{O}$ up to a final volume of $10 \mu \mathrm{L}$.

7. Load sample(s) in gel well(s) and run gel for approximately $40 \mathrm{~min}$ at $75 \mathrm{~V}$.

8. Visualize DNA with a standard transilluminator. The size of the amplification product in the cleavage reaction without His-AtRTL1 (non-cleaved RNA) is $\sim 100$ bp with primers UTRfw and UTRrev (Table 1). Non amplification product is detected in the cleavage reaction with His-AtRTL1 (cleaved RNA) and primers UTRfw and UTRrev (see Note 17)

\subsubsection{His-AtRTL1 Cleavage activity assay and two-step RT-PCR reaction}

The two-step RT-PCR reaction can be used as an alternative to the one-step RT-PCR kit.

1. Perform cleavage activity assay as described in Section 3.3.2, steps $1-2$.

2. In microtube 1 , mix $1 \mu \mathrm{L}$ of $10 \mu \mathrm{M}$ UTRrt primer, $2.5 \mu \mathrm{L}$ of cleavage reaction mix (with or without Hi-AtRTL1) from step 1 and RNase-free $\mathrm{H}_{2} \mathrm{O}$ up to a final volume of $5 \mu \mathrm{L}$. 
3. In microtube 2 , mix $4 \mu \mathrm{L}$ of GoScript ${ }^{\mathrm{TM}} 5 \mathrm{X}$ reaction buffer, $2.5 \mu \mathrm{L}$ of $10 \mathrm{mM} \mathrm{MgCl}_{2}, 1 \mu \mathrm{L}$ of $10 \mathrm{mM}$ dNTPs, $0.5 \mu \mathrm{L}$ of $40 \mathrm{U} / \mu \mathrm{L}$ RNasin, $1 \mu \mathrm{L}$ of $160 \mathrm{U} / \mu \mathrm{L}$ GoScript ${ }^{\mathrm{TM}}$ Reverse Transcriptase (RT), and RNase-free $\mathrm{H}_{2} \mathrm{O}$ up to a final volume of $15 \mu \mathrm{L}$.

4. Incubate microtube 1 for $5 \mathrm{~min}$ at $70^{\circ} \mathrm{C}$, spin the tube briefly so that all the sample can be collected at the bottom and then transfer the content to microtube 2. Mix thoroughly by pipetting up and down.

5. Transfer the mixture in a thermocycler and perform RT reactions with following parameters: annealing for $60 \mathrm{~min}$ at $42^{\circ} \mathrm{C}$, extension for $10 \mathrm{~min}$ at $70^{\circ} \mathrm{C}$, and final incubation for $10 \mathrm{~min}$ at $20^{\circ} \mathrm{C}$.

6. Set up PCR reactions by mixing $\sim 2 \mu \mathrm{L}$ of the cDNA obtained from step 5 with $5 \mu \mathrm{L}$ of $5 \mathrm{X}$ Go®Taq buffer, $1.5 \mu \mathrm{L}$ of $10 \mu \mathrm{M}$ UTRfwd, $1.5 \mu \mathrm{L}$ of $10 \mu \mathrm{M}$ UTRrev, $0.5 \mu \mathrm{L}$ of $10 \mathrm{mM}$ dNTP, $0.25 \mu \mathrm{L}$ of $5 \mathrm{U} / \mu \mathrm{L}$ Go®Taq DNA polymerase, and RNase-free $\mathrm{H}_{2} \mathrm{O}$ up to a final volume of $25 \mu \mathrm{L}$.

7. Transfer the mixtures in a thermocycler and perform PCR program with following parameters: step 1, initial denaturation $\left(94^{\circ} \mathrm{C}, 3 \mathrm{~min}\right)$; step 2, second cycle of denaturation $\left(94^{\circ} \mathrm{C}, 45 \mathrm{~s}\right)$; step 3, annealing $\left(55^{\circ} \mathrm{C}, 45 \mathrm{~s}\right)$; step 4, extension $\left(72^{\circ} \mathrm{C}, 60 \mathrm{~s}\right)$; step 5, final extension $\left(72^{\circ} \mathrm{C}, 10 \mathrm{~min}\right)$. Repeat steps $2-4$ for 34 times.

8. Analyze PCR products as described in Section 3.3.2, steps 5-8. 


\subsection{His-AtRTL1 Cleavage Activity Assay and Mapping Cleavage site}

All steps involving ${ }^{32} \mathrm{P}$-containing materials should be handled by properly trained staff, following local regulatory procedures.

\subsubsection{Primer radiolabeling}

1. For each relevant primer, set up a radiolabelling reaction by mixing $1 \mu \mathrm{L}$ of $10 \mu \mathrm{M}$ primer pe1 (or pe2; Table 1), $5 \mu \mathrm{L}$ of $\left[\gamma^{-32} \mathrm{P}\right]$ ATP $(50 \mu \mathrm{Ci} / \mu \mathrm{L} ; 3000 \mathrm{mmol} / \mathrm{mL}), 2 \mu \mathrm{L}$ of $10 \mathrm{X}$ PNK buffer, $1 \mu \mathrm{L}$ of T4 PNK, and $11 \mu \mathrm{L}$ of sterile deionized $\mathrm{H}_{2} \mathrm{O}$ for final volume of $20 \mu \mathrm{L}$. Incubate for $30 \mathrm{~min}$ at $37^{\circ} \mathrm{C}$.

2. To isolate the $\left[\gamma_{-}{ }^{32} \mathrm{P}\right]$ ATP radiolabelled primers from the non-incorporated $\left[\gamma^{32} \mathrm{P}\right]$ ATP, use a MicroSpin G-25 column or equivalent. Place the column into a $1.5 \mathrm{~mL}$ microtube and spin it for $1 \mathrm{~min}$ at $735 \mathrm{x} \mathrm{g}$. Recover the microSpin G-25 column and place it into a new 1.5 microtube, load the $20 \mu \mathrm{L}$ radiolabelling reaction and spin it for 2 min at $735 \mathrm{x} g$. Discard the microSpin G-25 column containing the non-incorporated $\left[\gamma_{-}{ }^{32} \mathrm{P}\right]$ ATP and save the radiolabelled primers collected in the bottom of the $1.5 \mathrm{~mL}$ microtube.

\subsubsection{Primer extension analysis}

1. Set up cleavage activity assay as described in Section 3.3.2, steps $1-2$, using $15 \mu \mathrm{g}$ of total RNA in each reaction (from Section 3.3.1). 
2. To remove His-AtRL1 protein and recover cleaved and/or non-cleaved RNA from cleavage reactions from step 1 , add to each sample $1 \mu \mathrm{L}$ of $5 \mathrm{mg} / \mathrm{mL}$ yeast tRNA, $79 \mu \mathrm{L}$ of RNase-free $\mathrm{H}_{2} \mathrm{O}$, and $100 \mu \mathrm{L}$ of phenol:chloroform:isoamyl alcohol (25:24:1), pH 5.2 premix solution. Mix well with a vortex mixer and centrifuge $15 \mathrm{~min}$ at $12,000 \mathrm{x} g$.

3. Recover aqueous (top) phase and add $10 \mu \mathrm{L}$ of $3 \mathrm{M}$ sodium acetate $\mathrm{pH} 5.2$ and $300 \mu \mathrm{L}$ of $100 \%$ ethanol. Incubate overnight at $-20^{\circ} \mathrm{C}$

4. Centrifuge at $12,000 \times g$ for $15 \mathrm{~min}$ at $4^{\circ} \mathrm{C}$. Discard the supernatant and rinse the pellet by adding $1 \mathrm{~mL}$ of cold $80 \%$ ethanol.

5. Suspend the RNA pellet in $6 \mu \mathrm{L}$ of RNase-free $\mathrm{H}_{2} \mathrm{O}$.

6. Set up primer extension annealing mix by combining the $6 \mu \mathrm{L}$ of RNA from step 5 with 2 $\mu \mathrm{L}$ of $5 \mathrm{X}$ Superscript II RT buffer and $2 \mu \mathrm{L}$ of radiolabeled primer (from Section 3.4.1, step 2 (see Note 18). Incubate for $5 \mathrm{~min}$ at $80^{\circ} \mathrm{C}$ in a dry bath.

7. Cool down the reactions to $52^{\circ} \mathrm{C}$ by removing the heat block from the dry bath. Do not allow the temperature of the block to go lower than $52^{\circ} \mathrm{C}$.

8. In a new $1.5 \mathrm{~mL}$ microtube, set up the primer extension RT mix by combining $0.5 \mu \mathrm{L}$ of 40 $\mathrm{U} / \mu 1 \mathrm{RNasin}, 2 \mu \mathrm{L}$ of $10 \mathrm{mM}$ dNTPs, $2 \mu \mathrm{L}$ of $5 \mathrm{X}$ Superscript II RT buffer, $2 \mu \mathrm{L}$ of $100 \mathrm{mM}$ DTT, $3 \mu \mathrm{L}$ of RNase-free $\mathrm{H}_{2} \mathrm{O}$ and $0.5 \mu \mathrm{L}$ of Superscript II RT enzyme. Keep the primer extension $\mathrm{RT}$ mix at $52^{\circ} \mathrm{C}$ in a dry bath.

9. Mix $10 \mu \mathrm{L}$ of primer extension annealing (step 2) with $10 \mu \mathrm{L}$ of primer extension RT (step 8) mixtures. Incubate $1 \mathrm{~h}$ at $52{ }^{\circ} \mathrm{C}$. 
10. Spin the tube briefly and stop primer extension reactions by adding $2 \mu \mathrm{L}$ of $3 \mathrm{M}$ sodium acetate $\mathrm{pH} 5.2,1 \mu \mathrm{L}$ of $5 \mathrm{mg} / \mathrm{mL}$ tRNA and $60 \mu \mathrm{L}$ of $100 \%$ ethanol. Precipitate RNA overnight at $-20^{\circ} \mathrm{C}$.

11. Centrifuge at $12,000 \mathrm{x} g$ for $15 \mathrm{~min}$ at $4^{\circ} \mathrm{C}$. Discard the supernatant and rinse the pellet with $1 \mathrm{~mL}$ of cold $80 \%$ ethanol.

12. Centrifuge at $12,000 \times g$ for $5 \mathrm{~min}$ at $4^{\circ} \mathrm{C}$. Remove carefully the supernatant and air dry the pellet at room temperature.

13. Install a denaturing, $6 \%$ Urea-PAGE gel in a vertical electrophoresis system. Remove comb and fill system tanks with $1 \mathrm{X}$ TBE buffer. Pre-run the gel for 40-60 min to heat the gel up and to remove remaining urea from the gel. The optimal temperature should be between 45$55{ }^{\circ} \mathrm{C}$ (see Note 19). Turn off the power and flush gel wells with $1 \mathrm{X}$ TBE buffer to eliminate diffusing urea from the wells.

14. Suspend the pellets from step 12 in $10 \mu \mathrm{L}$ of Formamide loading buffer and heat samples in a dry bath for 2 min at $95^{\circ} \mathrm{C}$.

15. Spin the tube briefly and load samples in gel wells and run the gel until the blue dye reaches at least $2 / 3$ of the gel ( $30 \mathrm{~min})$ (see Note 19).

16. Remove gel from apparatus and pry one gel plate apart with a spatula. Transfer gel on a piece of Whatman paper and cover the free gel face with saran wrap. Dry gel on a vacuum heated gel dryer and expose it to a ${ }^{32} \mathrm{P}$ imaging screen in an imaging cassette for 5 to $12 \mathrm{hrs}$. Then screen image with a Phosphor-Imager. Primer extension reaction with primer pe1 yield products of $\sim 42$ - and $\sim 46-$ nt long while reaction with primer pe 2 yield products of $\sim 38$ - and 42-nt long and map the RTL1 cleavage site rcr1 in each RNA strand of the 3'UTR (Figures 2B) (see Note 20). 


\subsection{His-AtRTL1 Cleavage Activity Assay Using Radiolabelled RNA probes}

\subsubsection{Making radiolabelled probe}

1. Linearize $\sim 1 \mu \mathrm{g}$ of the pBSIIk +3 'UTRrcr plasmid with Kpn1 restriction enzyme, following supplier's instructions (see Note 21). Purify linearized plasmid with a DNA cleanup kit following kit instructions (see Note 22).

2. Set up in vitro transcription reaction by mixing $5 \mu \mathrm{L}$ of $5 \mathrm{X}$ Transcription buffer, $2.5 \mu \mathrm{L}$ of $100 \mathrm{mM}$ DTT, $5 \mu \mathrm{L}$ of $2.5 \mathrm{mM}$ rGTP, rATP, rUTP solution, $3 \mu \mathrm{L}$ of $100 \mu \mathrm{M} \mathrm{rCTP}, \sim 0.2 \mu \mathrm{g}$ of Kpn1 linearized pBSIIk+ 3'UTRrcr plasmid from step 1, $5 \mu \mathrm{L}$ of $\left[\alpha-{ }^{32} \mathrm{P}\right] \mathrm{CTP}(10 \mu \mathrm{Ci} / \mu \mathrm{L}$, $3000 \mathrm{Ci} / \mathrm{mmol}$ ), $1 \mu \mathrm{L}$ of $20 \mathrm{U} / \mu \mathrm{L}$ T3 RNA Polymerase and RNase-free $\mathrm{H}_{2} \mathrm{O}$ up to a final volume of $25 \mu \mathrm{L}$. Incubate reaction for $120 \mathrm{~min}$ at $37^{\circ} \mathrm{C}$.

3. Stop the T3 RNA Polymerase transcription reaction by precipitation as described in Section 3.4.2 steps $10-12$.

4. Install a denaturing, $6 \%$ Urea-PAGE gel in a vertical electrophoresis system. Remove comb and fill system tanks with $1 \mathrm{X}$ TBE buffer. Pre-run the gel for 40-60 min before sample loading (see Note 19 and Section 3.4.2 step 13). Turn off the power and flush gel wells with 1X TBE buffer to eliminate diffusing urea from the wells.

5. Dissolve pellet from step 3 in $6 \mu \mathrm{L}$ of Formamide loading buffer and heat sample in a dry bath for 2 min at $95^{\circ} \mathrm{C}$.

6. Spin the tubes briefly and load samples in gel wells and run the gel until the blue dye reaches at least $2 / 3$ of the gel $(\sim 30 \mathrm{~min})$. 
7. Remove gel from apparatus and pry one gel plate apart with a spatula. Cover the free gel face with saran wrap and expose it to a ${ }^{32} \mathrm{P}$ imaging screen in an imaging cassette for $5 \mathrm{~min}$.

8. Print a highly contrasted gel image at exact size and place it under the gel plate, carefully aligning the actual gel with the gel image (see Note 23).

9. Using a clean scalpel blade, cut out the piece of gel containing the radiolabeled transcript and place it in a $1.5 \mathrm{~mL}$ microtube containing $500 \mu \mathrm{L}$ of RNA elution solution. Incubate for $2 \mathrm{~h}$ at $37^{\circ} \mathrm{C}$.

10. Centrifuge at $12,000 \times \mathrm{g}$ for $5 \mathrm{~min}$ at room temperature. Transfer the supernatant to a new 2 $\mathrm{mL}$ microtube and add $1.5 \mathrm{~mL}$ of $100 \%$ ethanol. Precipitate the ${ }^{32} \mathrm{P}$-labelled RNA overnight at $-20^{\circ} \mathrm{C}$.

11. Centrifuge at $12,000 \times g$ for $15 \mathrm{~min}$ at $4^{\circ} \mathrm{C}$. Discard the supernatant and rinse the pellet with $1 \mathrm{~mL}$ of cold $80 \%$ ethanol.

12. Centrifuge at $12,000 \times \mathrm{g}$ for $5 \mathrm{~min}$ at $4^{\circ} \mathrm{C}$. Remove carefully the supernatant, air dry the pellet and suspend it in $50 \mu \mathrm{L}$ of RNase-free $\mathrm{H}_{2} \mathrm{O}$. Store the ${ }^{32} \mathrm{P}$-labeled RNA stock solution at $20^{\circ} \mathrm{C}$ until further use.

\subsubsection{Cleavage reaction of radiolabelled probe and analysis on denaturing PAGE}

1. Mix $1 \mu \mathrm{L}$ of ${ }^{32} \mathrm{P}$-labeled RNA stock solution (from Section 3.5.1, step 12) with $10 \mu \mathrm{L}$ of RNase-free, deionized water.

2. Setup cleavage reaction by mixing $4 \mu \mathrm{L}$ of the ${ }^{32} \mathrm{P}$-labeled RNA dilution from step 1 with 4 $\mu \mathrm{L}$ of 5X Cleavage reaction buffer, $~ 200 \mathrm{ng}$ of His-AtRTL1 (from Section 3.2.1, step 20 or 
Section 3.2.2, step 6) and RNase-free $\mathrm{H}_{2} \mathrm{O}$ up to a final volume of $20 \mu \mathrm{L}$. Also prepare a cleavage reaction mix with protein sample buffer instead of His-AtRTL1 protein (see Note 15). Incubate for $\sim 30 \mathrm{~min}$ at $37^{\circ} \mathrm{C}$.

3. Stop reaction by heating samples for $5 \mathrm{~min}$ at $70^{\circ} \mathrm{C}$. Spin the tube briefly so that all the sample can be collected at the bottom. Then, add $1 \mu \mathrm{L}$ of $5 \mathrm{mg} / \mathrm{mL}$ yeast tRNA, $79 \mu \mathrm{L}$ of RNase-free $\mathrm{H}_{2} \mathrm{O}$, and $100 \mu \mathrm{L}$ of phenol:chloroform:isoamyl alcohol (25:24:1), pH 5.2 premix solution. Mix well with a vortex mixer and centrifuge $15 \mathrm{~min}$ at $12,000 \mathrm{x} g$.

4. Recover aqueous (top) phase and add $10 \mu \mathrm{L}$ of $3 \mathrm{M}$ sodium acetate $\mathrm{pH} 5.2$ and $300 \mu \mathrm{L}$ of $100 \%$ ethanol. Incubate overnight at $-20^{\circ} \mathrm{C}$

5. Centrifuge at $12,000 \times g$ for $15 \mathrm{~min}$ at $4^{\circ} \mathrm{C}$. Discard the supernatant and rinse the pellet by adding $1 \mathrm{~mL}$ of cold $80 \%$ ethanol.

6. Centrifuge at $12,000 \times g$ for $5 \min$ at $4^{\circ} \mathrm{C}$. Remove carefully the supernatant and suspend the pellet in $10 \mu \mathrm{L}$ of Formamide loading buffer.

7. Install a denaturing, $6 \%$ Urea-PAGE gel in a vertical electrophoresis system as described in Section 3.5.1 step 4 .

8. Heat sample from step 6 in a dry bath for 2 min at $95^{\circ} \mathrm{C}$. Spin the tube briefly and load sample in gel well and run the gel until the blue dye reaches at least $2 / 3$ of the gel ( $30 \mathrm{~min}$ ) (see Notes 19).

9. Process and image gel as described in Section 3.4.2, step 16. The non-cleaved, ${ }^{32} \mathrm{P}-$ labelled RNA probe migrates as a $\sim 240$ nt-long RNA while cleaved ${ }^{32} \mathrm{P}$-labelled RNA probe migrate as two $\sim 110$ and $\sim 105$ nt-long fragments (Figure 3C). 


\section{Notes}

1. pET16b::AtRTL1 is a derivative of the commercial pET16b expression plasmid (Novagen) containing the full length AtRTL1 coding sequence and located downstream from a sequence encoding a hexa histidine-tag (6XHis-tag) and under control of a T7 promoter (Figure 3A). The plasmid allows overexpression of the N-terminal His-tagged AtRTL1 (His-AtRTL1) protein in E. coli cells.

2. Compared to standard BL21 cells, SoluBL21 cells yield higher amount of soluble His-AtRL1 protein.

3. Cobalt chelating resins may be used instead of Ni-NTA. Non-specific binding contaminants may be fewer but usually at the expense of yield of the expected protein. Prepacked Ni-NTA or Cobalt resin columns installed on a FPLC system can also be used.

4. pBSIIk+3'UTR plasmid contains the sequence 3'UTR-rcr1 (Figure 2B) cleavage site from At3g18145 gene [33].

5. We use distinct volume aliquots of the original cell culture to increase chances to obtain wellisolated bacterial colonies. Using freshly isolated colonies rather than the $-80^{\circ} \mathrm{C}$ stock to express proteins limits risk of plasmid loss and usually increases yields of expressed proteins.

6. We use a cell disruptor from Constant Systems Limited at a pressure of 1.35 bar. Alternatively you can use sonication or a French press to disrupt E. coli cells and release recombinant HisAtRLT1.

7. AtRTL1 is $\sim 34 \mathrm{kDa}$ and the 6 XHis-tag is $\sim 1 \mathrm{Kda}$.

8. You can perform a second dialysis round of 5-8 h using fresh protein sample buffer.

9. In our hands and with an AKTA purifier system (GE-Healthcare), conalbumin, ovalbumin, and carbonic anhydrase elute at $\sim 11, \sim 12$, and $\sim 13 \mathrm{~mL}$, respectively. 
10. One may also detect His-RTL1 protein by Western Blotting using anti-AtRTL1 (custommade) or anti-His-Tag (commercial) antibodies.

11. Alternatively, frozen seedlings can be grinded in a mortar with a pestle and using liquid nitrogen to create a fine powder.

12. We use a $\sim 1.5 \mu \mathrm{L}$ aliquot to measure absorbance at $260 \mathrm{~nm}$ with a NanoDrop 2000 spectrophotometer. We then estimate RNA concentration from the absorbance using an extinction coefficient of $40 \mathrm{ng}-\mathrm{cm} / \mu \mathrm{L}$.

13. This step avoids the need DNase inactivation by heat and/or phenol extraction.

14. In the agarose gel, large (25S and $18 \mathrm{~S})$, small (5.8S, $5 \mathrm{~S}$ and tRNA) as well as chloroplast RNAs are visualized. You can verify lack of DNA contamination by PCR, using primers that amplify a genomic sequence containing introns and exons (for instance eIF1 $\alpha$ gene sequence [34]). If the RNA sample is DNA-free, no amplification should be detected. Use a genomic DNA sample as a positive control of amplification.

15. Using RNA sample buffer instead of His-AtRTL1 allows to detect absence of RNA cleavage in absence of RTL1 activity.

16. U3fw and U3rev are specific primers for the amplification of snoRNA U3 sequences which are not cleaved by AtRTL1 and then used to control RNA loading and specific RNA cleavage of At3g18145-3'UTR.

17. Primers UTRfw/UTRrev amplify non-cleaved At3g18145-3'UTR RNA sequences (97 bp) while primers U3fw/U3rev amplify U3snoRNA (215 bp) sequences.

18. As a negative reaction control, set a primer extension assays with $10 \mu \mathrm{g}$ of yeast tRNA instead of plant total RNA in cleavage reactions with and without His-AtRTL1 protein. 
19. Run settings depend on gel size. We run $0.4 \mathrm{~mm}$ wide gels at $18 \mathrm{~W}(22 \times 20 \mathrm{~cm}$ gels $)$ or 45 $\mathrm{W}(42 \times 20 \mathrm{~cm}$ gels$)$.

20. To estimate primer extension size products, one may load a radiolabeled DNA size ladder alongside with samples on the gel. There are various ways to prepare such ladders. For instance, one nucleotide resolution ladders can be prepared by Sanger sequencing of the pGemT-3'UTR_At3g18145 plasmid with ${ }^{32} \mathrm{P}-$ labeled pe1 and pe2 primers [35].

21. The Kpn1 site is located downstream of the 3'UTRrcr sequence and the T3 promoter is located upstream of the 3'UTRrcr sequence (Figure 3B).

22. Alternatively, you may heat-inactivate $\mathrm{Kpn} 1$ at $65^{\circ} \mathrm{C}$ for $20 \mathrm{~min}$ and purify the plasmid by extraction with a buffer-saturated $(\mathrm{pH}$ 8) Phenol:chloroform:isoamyl alcohol (25:24:1) solution and, then, by ethanol precipitation.

23. Alternatively, you can stick pieces of Whatman paper to the corners of the gel and pipet $1 \mu \mathrm{L}$ of a blue colored radioactive solution (e.g. $1 \mu \mathrm{L}$ of labelled primer from section 3.4.1 in 10 $\mu \mathrm{L}$ of $6 \mathrm{X}$ Formamide loading buffer) on each piece. These highly radioactive spots will help align the gel with the gel image.

\section{Acknowledgments}

This work was supported by the CNRS and by a grant from the ANR (Agence Nationale de la Recherche): RiboStress 17-CE12-0026-01 and EpiRNase ANR-11-BSV6-007. This study is set within the framework of the "Laboratoires d'Excellences (LABEX) TULIP (ANR-10-LABX-41). 


\begin{tabular}{|l|l|l|}
\hline \multicolumn{2}{|l|}{ Table 1 : DNA oligonucleotide primers } \\
\hline Name & Sequence & Usage \\
\hline UTRfw & AGCGTACTTGTGCAAAATGCG & One Step RT-PCR and PCR \\
\hline UTRrev & GTCAGTCTGTAATAGCTC & One Step RT-PCR and PCR \\
\hline UTRrt & CTTTAGTTACAAAACAAAACC & Reverse Transcription (RT) \\
\hline U3fw & ACGGACCTTACTTGAACAGGATCTG & One Step RT-PCR-control \\
\hline U3rev & CTGTCAGACCGCCGTGCG & One Step RT-PCR-control \\
\hline pe1 & GTCAGTCTGTAATAGCTC & Primer extension \\
\hline pe2 & GCAAAATACCAGATCCAG & Primer extension \\
\hline
\end{tabular}




\section{Figure Legends}

A

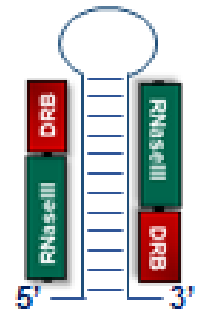

dsRNA

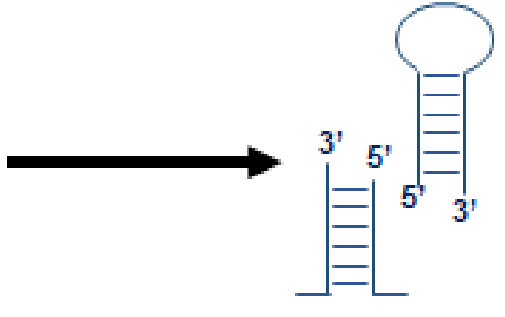

Cleaved dsRNA
B

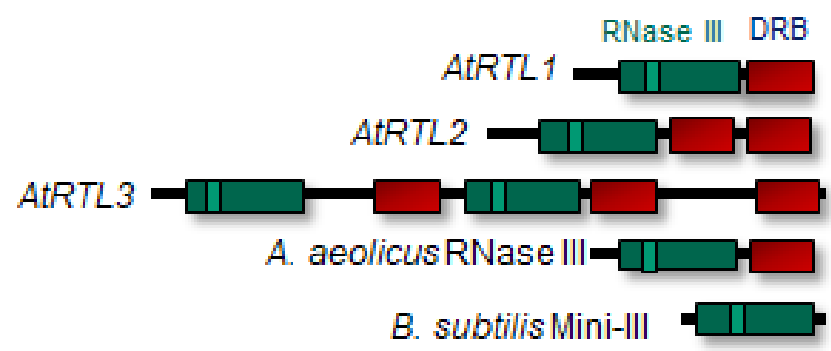

Figure 1: A) RNase III homodimer cleaves double-strand RNA (dsRNA) and generates 3' overhang ends. B) Schematic comparing Class I RNases III from Arabidopsis thaliana (AtRTL1-3), Aquifex aeolicus (RNase III) and Bacillus subtilis (Mini-RNase III). Green and red boxes correspond to RNase III and DRB domains while light green boxes correspond to the conserved RNase III motif. 

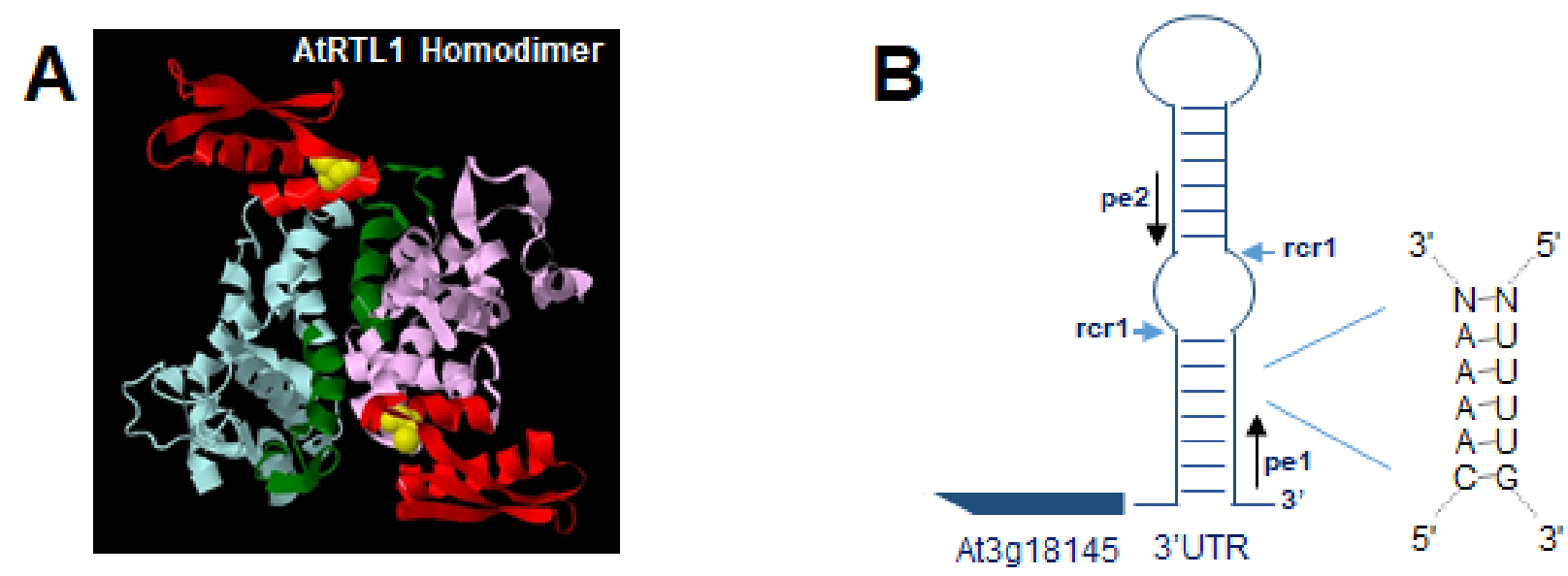

Figure 2: A) Modelled AtRTL1 (residues 50-284) homodimer based on Aquifex aeolicus (PDB: 1YYW) [5]. The RNase III motifs of two AtRTL1 molecules are shown in green while both DRBs are shown in red. Cys230 residues in the DRBs are shown in yellow. B) AtRTL1 cleavage site rcr1 in the At3g18145 3'UTR sequence is located near to conserved RNA duplex that directs accurate cleavage. The positions of pe1 and pe2 primers used in primer extension experiments are indicated. [7]. 
A

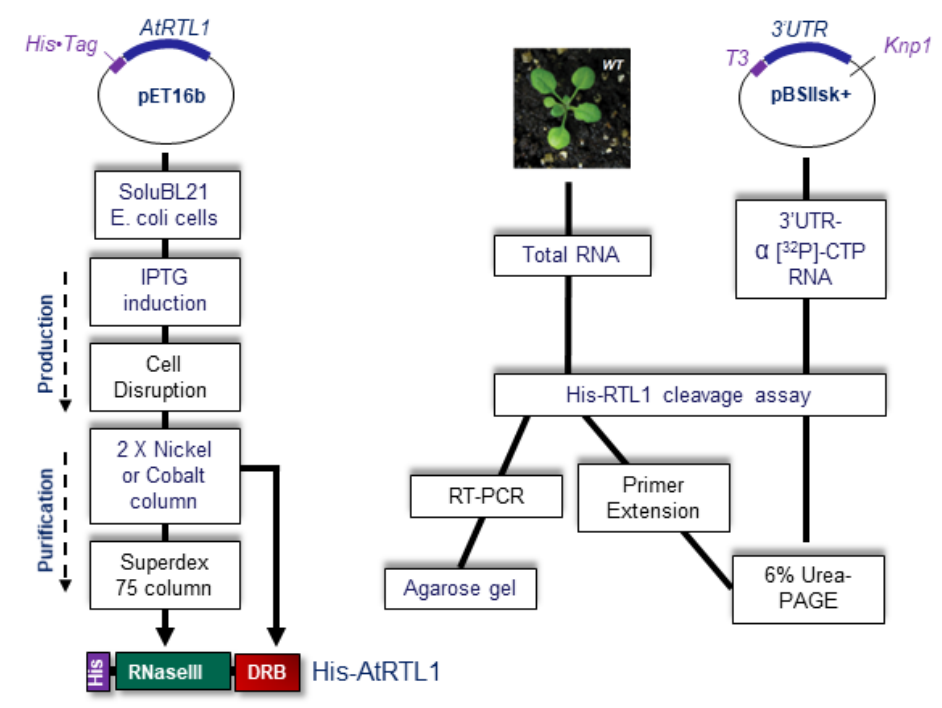

B

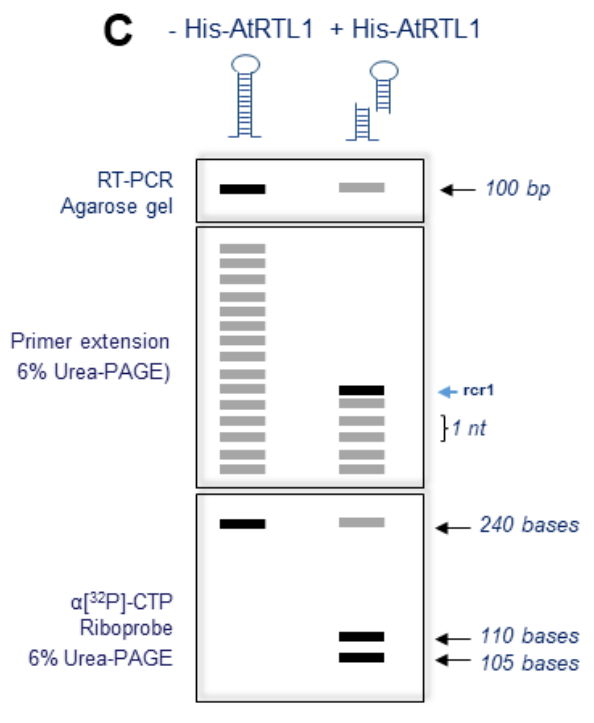

Figure 3: Schematic representation of A) His-AtRTL1 purification. Green and red boxes correspond to RNase III and DRB domains of AtRTL1 while the purple box corresponds to the N-terminal 6XHis-tag sequence in the His-RTL1 protein. B) in vitro cleavage assays using Arabidopsis total RNA or ${ }^{32}$ P-labelled 3'UTR-RNA. C) $\underline{\text { Top}}$, RT-PCR analysis on agarose gel: non-cleaved RNA can be amplified using specific UTRfw and UTRrev primers located upstream/downstream of AtRTL1 cleavage site rcr1 ( $100 \mathrm{bp})$ while cleaved RNA it is not amplified. Middle, analysis on denaturing gel of primer extension reactions. Primer pe1 detects 42- and 46-nt long products while primer pe2 detects 38- and 42-nt long products. Bottom, on denaturing gel the non-cleaved radiolabeled probe migrates as a 240 nt-long RNAs while the His-AtRTL1cleaved RNAs migrate as 110 and 105 nt-long fragments. 


\section{References}

1. Court, D. L., Gan, J., Liang, Y. H. et al. (2013) RNase III: Genetics and function; structure and mechanism. Annu Rev Genet 47:405-431. doi:10.1146/annurev-genet-110711-155618

2. Filippov, V., Solovyev, V., Filippova, M. et al. (2000) A novel type of RNase III family proteins in eukaryotes. Gene 245 (1):213-221.

3. Nicholson, A. W. (1999) Function, mechanism and regulation of bacterial ribonucleases. FEMS Microbiol Rev 23 (3):371-390.

4. Nicholson, A. W. (2014) Ribonuclease III mechanisms of double-stranded RNA cleavage. Wiley Interdiscip Rev RNA 5 (1):31-48. doi:10.1002/wrna.1195

5. Blaszczyk, J., Tropea, J. E., Bubunenko, M. et al. (2001) Crystallographic and modeling studies of RNase III suggest a mechanism for double-stranded RNA cleavage. Structure 9 (12):1225-1236.

6. Gan, J., Tropea, J. E., Austin, B. P. et al. (2006) Structural insight into the mechanism of doublestranded RNA processing by ribonuclease III. Cell 124 (2):355-366. doi:10.1016/j.cell.2005.11.034

7. Olmedo, G.,Guzman, P. (2008) Mini-III, a fourth class of RNase III catalyses maturation of the Bacillus subtilis 23S ribosomal RNA. Mol Microbiol 68 (5):1073-1076. doi:10.1111/j.1365-

2958.2008.06203.x

8. Lamontagne, B., Tremblay, A.,Abou Elela, S. (2000) The N-terminal domain that distinguishes yeast from bacterial RNase III contains a dimerization signal required for efficient double-stranded RNA cleavage. Mol Cell Biol 20 (4):1104-1115.

9. Liang, Y. H., Lavoie, M., Comeau, M. A. et al. (2014) Structure of a eukaryotic RNase III postcleavage complex reveals a double-ruler mechanism for substrate selection. Mol Cell $\mathbf{5 4}$ (3):431-444. doi:10.1016/j.molcel.2014.03.006

10. Rotondo, G.,Frendewey, D. (1996) Purification and characterization of the Pac1 ribonuclease of Schizosaccharomyces pombe. Nucleic Acids Res 24 (12):2377-2386.

11. Bernstein, E., Caudy, A. A., Hammond, S. M. et al. (2001) Role for a bidentate ribonuclease in the initiation step of RNA interference. Nature 409 (6818):363-366. doi:10.1038/35053110

12. Carmell, M. A.,Hannon, G. J. (2004) RNase III enzymes and the initiation of gene silencing. Nat Struct Mol Biol 11 (3):214-218.

13. Kwon, S. C., Nguyen, T. A., Choi, Y. G. et al. (2016) Structure of Human DROSHA. Cell 164 (1-2):81-90. doi:10.1016/j.cell.2015.12.019

14. Du, Z., Lee, J. K., Tjhen, R. et al. (2008) Structural and biochemical insights into the dicing mechanism of mouse Dicer: a conserved lysine is critical for dsRNA cleavage. Proc Natl Acad Sci U S A 105 (7):2391-2396. doi:10.1073/pnas.0711506105

15. Macrae, I. J., Zhou, K., Li, F. et al. (2006) Structural basis for double-stranded RNA processing by Dicer. Science 311 (5758):195-198. doi:10.1126/science.1121638 
16. Margis, R., Fusaro, A. F., Smith, N. A. et al. (2006) The evolution and diversification of Dicers in plants. FEBS Lett $\mathbf{5 8 0}$ (10):2442-2450. doi:10.1016/j.febslet.2006.03.072

17. Zhang, H., Kolb, F. A., Jaskiewicz, L. et al. (2004) Single processing center models for human Dicer and bacterial RNase III. Cell 118 (1):57-68. doi:10.1016/j.cell.2004.06.017

18. Fukudome, A.,Fukuhara, T. (2017) Plant dicer-like proteins: double-stranded RNA-cleaving enzymes for small RNA biogenesis. J Plant Res 130 (1):33-44. doi:10.1007/s10265-016-0877-1

19. Xie, Z., Kasschau, K. D.,Carrington, J. C. (2003) Negative feedback regulation of Dicer-Like1 in Arabidopsis by microRNA-guided mRNA degradation. Curr Biol 13 (9):784-789.

20. Zhu, H., Zhou, Y., Castillo-Gonzalez, C. et al. (2013) Bidirectional processing of pri-miRNAs with branched terminal loops by Arabidopsis Dicer-like1. Nat Struct Mol Biol 20 (9):1106-1115. doi: $10.1038 /$ nsmb.2646

21. Henderson, I. R., Zhang, X., Lu, C. et al. (2006) Dissecting Arabidopsis thaliana DICER function in small RNA processing, gene silencing and DNA methylation patterning. Nat Genet 38 (6):721-725.

22. Nagano, H., Fukudome, A., Hiraguri, A. et al. (2014) Distinct substrate specificities of Arabidopsis DCL3 and DCL4. Nucleic Acids Res 42 (3):1845-1856. doi:10.1093/nar/gkt1077

23. Parent, J. S., Bouteiller, N., Elmayan, T. et al. (2015) Respective contributions of Arabidopsis DCL2 and DCL4 to RNA silencing. Plant $J 81$ (2):223-232. doi:10.1111/tpj.12720

24. Xie, Z., Johansen, L. K., Gustafson, A. M. et al. (2004) Genetic and functional diversification of small RNA pathways in plants. PLoS Biol 2 (5):E104. doi:10.1371/journal.pbio.0020104

25. Borges, F.,Martienssen, R. A. (2015) The expanding world of small RNAs in plants. Nat Rev Mol Cell Biol 16 (12):727-741. doi:10.1038/nrm4085

26. Elvira-Matelot, E., Martínez, A. E.,Vaucheret, H. (2017) Diversity of RNA Silencing Pathways in Plants. In: T. Dalmay (ed) Plant Gene Silencing: Mechanisms and Applications. vol 5. CABI Biotechnology Series, Oxfordshire, UK, pp 1-31

27. Pikaard, C. S.,Mittelsten Scheid, O. (2014) Epigenetic regulation in plants. Cold Spring Harb Perspect Biol 6 (12):a019315. doi:10.1101/cshperspect.a019315

28. Comella, P., Pontvianne, F., Lahmy, S. et al. (2008) Characterization of a ribonuclease III-like protein required for cleavage of the pre-rRNA in the 3'ETS in Arabidopsis. Nucleic Acids Res 36 (4):1163-1175. doi:10.1093/nar/gkm1130

29. Shamandi, N., Zytnicki, M., Charbonnel, C. et al. (2015) Plants Encode a General siRNA Suppressor That Is Induced and Suppressed by Viruses. PLoS Biol 13 (12):e1002326. doi:10.1371/journal.pbio.1002326

30. Kiyota, E., Okada, R., Kondo, N. et al. (2011) An Arabidopsis RNase III-like protein, AtRTL2, cleaves double-stranded RNA in vitro. J Plant Res 124 (3):405-414. doi:10.1007/s10265-010-0382$\mathrm{X}$ 
31. Elvira-Matelot, E., Hachet, M., Shamandi, N. et al. (2016) Arabidopsis RNASE THREE LIKE2 Modulates the Expression of Protein-Coding Genes via 24-Nucleotide Small Interfering RNADirected DNA Methylation. Plant Cell 28 (2):406-425. doi:10.1105/tpc.15.00540

32. Hotto, A. M., Castandet, B., Gilet, L. et al. (2015) Arabidopsis Chloroplast Mini-Ribonuclease III Participates in rRNA Maturation and Intron Recycling. Plant Cell 27 (3):724-740. doi:10.1105/tpc.114.134452

33. Charbonnel, C., Niazi, A. K., Elvira-Matelot, E. et al. (2017) The siRNA suppressor RTL1 is redox-regulated through glutathionylation of a conserved cysteine in the double-stranded-RNAbinding domain. Nucleic Acids Res 45 (20):11891-11907. doi:10.1093/nar/gkx820

34. Durut, N., Abou-Ellail, M., Pontvianne, F. et al. (2014) A duplicated NUCLEOLIN gene with antagonistic activity is required for chromatin organization of silent 45S rDNA in Arabidopsis. Plant Cell 26 (3):1330-1344. doi:10.1105/tpc.114.123893

35. Saez-Vasquez, J., Caparros-Ruiz, D., Barneche, F. et al. (2004) A plant snoRNP complex containing snoRNAs, fibrillarin, and nucleolin-like proteins is competent for both rRNA gene binding and pre-rRNA processing in vitro. Mol Cell Biol 24 (16):7284-7297.

doi:10.1128/mcb.24.16.7284-7297.2004 